ЛЕВЕНЕЦЬ Б. Б., аспірант відділу теорії держави і права (Інститут держави і права імені В. М. Корецького

Національної академії наук України)

УДК 340.5:340.137.3

DOI https://doi.org/10.32842/2078-3736-2019-6-1-9

\title{
МОДЕЛІ СУДОВОГО ПРАВОЗАСТОСУВАННЯ УКРАЇНИ ТА ФРАНЦЇ̈: ПОРІВНЯЛЬНО-ПРАВОВЕ ДОСЛІДЖЕННЯ
}

У статті проведено порівняльно-правовий аналіз моделей судового правозастосування України та Франції. Із застосуванням історичного методу досліджено еволюцію джерел права континентальної правової сім'ї, розвиток судового права та поширення судового прецеденту.

Особливістю судового правозастосування у європейських державах є широке використання практики звернення до судових прецедентів, вироблених Європейським судом $з$ прав людини, а також судових рішень країн континентальної Європи.

Система судоустрою Франції порівняно з вітчизняною є складною та розгалуженою, оскільки до іiі складу включені суди та трибунали з різною спеціалізацією, квазісудові органи. $€$ також моделі одноособових та колективних судів. Французька модель конституційного та адміністративного контролю здійснюється двома органами - Конституційною радою та Державною радою.

Спільними рисами моделей судового правозастосування в межах цивільного процесу України та Франції є: використання принципів цивільного судочинства (верховенства права, змагальності, публічності, пропорційності, можливості оскарження судового рішення тощо); використання позову як форми звернення до суду; проведення підготовчого засідання; наявність моделі доказування та судових дебатів; можливості оскарження судових рішень. Згідно з французькою моделлю судових рішень приймаються судові постанови 3 проміжних питань, остаточні та змішані рішення. Особливостями французької моделі судового правозастосування є: можливість подання спільної заяви, що містить взаємні позовні вимоги, спірні питання та аргументи; застосування процедур примирення сторін; свобода вибору довіреної особи - представника. В Україні у більшості справ представництво в суді здійснюється винятково адвокатом, за винятком справ щодо розгляду трудових спорів, захисту соціальних прав, виборів та референдумів, у малозначних спорах тощо.

Ключові слова: модель судового правозастосування, континентальне право, судоустрій, Свропейський суд з прав людини, модель конституиійного контролю, змагальна прочедура, позов, спільна заява, судові дебати, доказування, види судових рішень, змішані рішення, посередництво.

The article presents a comparative legal analysis of models of judicial enforcement of Ukraine and France. Using the historical method, the evolution of the sources of continental law family law, the development of judicial law, and the spread of judicial precedent have been investigated.

The model of judicial enforcement of European countries is characterized by the fact that the practice of recourse to judicial precedents made by the European

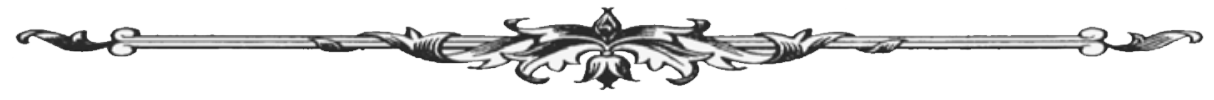


Court of Human Rights, as well as the judgments of continental European countries, is expanding.

The judicial system of France, in comparison with the domestic system, is complex and extensive, since it includes courts and tribunals with different specialization, quasi-judicial authorities. There are models of single and collective courts. The French model of constitutional and administrative control is implemented by two authority authorities - the Constitutional Council and the State Council.

Common features of models of judicial enforcement of the civil process of Ukraine and France are: the principles of civil justice (the rule of law, competitiveness, publicity, proportionality, the possibility of appealing a court decision, etc.); a claim as a form of appeal; holding a preparatory meeting; models of evidence and judicial debate; models of court decisions; the possibility of their appeal. Types of court decisions are: final, intermediate court decisions, mixed decisions. The differences between the French model of judicial enforcement are expressed by: the possibility of filing a joint application containing mutual claims, disputes and arguments; applying the parties' conciliation procedures; the freedom to choose a proxy - representative, in the vast majority of cases in Ukraine, is represented solely by a lawyer.

Key words: model of judicial enforcement, continental law, judiciary, European Court of Human Rights, model of constitutional control, competitive procedure, lawsuit, joint statement, judicial debate, evidence, types of court decisions, mixed decisions, mediation.

Вступ. За усієї різноманітності моделей судового правозастосування наразі в сучасному світі $є$ тенденція зближення ідеології судочинства держав континентальної правової сім'ї. Наближення відбуваються з огляду на дотримання положень Конвенції про захист прав людини й основоположних свобод, втілення у національне судочинство принципів, вироблених Європейським судом з прав людини (далі - ЄСПЛ), зміцнення та збагачення філософії прав людини.

Континентальне право або право цивільно-правової традиції походить з Європи та $€$ інтелектуалізованим у межах давньоримського права. Суттєвий зв'язок континентальної правової сім'ї з римським правом зумовлений його рецепцією - відтворенням високорозвиненої системи права, що існувала раніше $[1$, с. 50]. Серед особливостей континентальної правової сім'ї можна зазначити такі: значний вплив на формування та розвиток права діяльності університетів; кодифікований характер права, його поділ на публічне і приватне; верховенство права та вища юридична сила закону. Зміст верховенства права зумовлений значущістю права як соціально-культурного явища, що має найбільший соціально-регулятивний потенціал у суспільстві. Жоден з інших регуляторів (моральні канони, звичаї, традиції тощо) не мав такого зовнішнього впливу на упорядкування поведінки суб'єктів, як право [2, с. 295]. Первинним джерелом права в континентальній правовій сім'ї є нормативно-правовий акт, що з'явився на початкових стадіях розвитку державності та став провідним, поступово витіснивши правові звичаї та доктрину. 3 підвищенням авторитету державної влади, iї централізацією, пріоритетного значення набула діяльність законодавчих органів, а право одержує зовсім іншу, авторитетну зовнішню форму вираження - закон [3, с. 191]. Тривалий час судовий прецедент вважався вторинним джерелом права в державах континентальної правової сім’ї. Водночас наразі спостерігається тенденція до зростання ролі судового прецеденту, чому сприяють як недосконалість законодавства, так і впливовість судової практики. Таким чином, сукупність зазначених характеристик справили значний вплив на формування та розвиток моделі судового правозастосування континентальної правової сім’і, зокрема й таких ії представників, як Україна та Франція.

Аналіз останніх досліджень і публікацій. Зазначимо, що комплексні порівняльно-правові дослідження моделей судового правозастосування України та Франції відсутні,

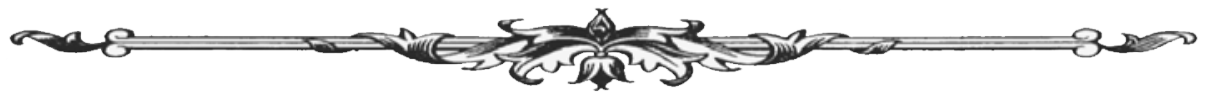


проте окремі аспекти структури, стадій судового правозастосування, форм судочинства, принципів, системи судоустрою досліджували такі учені, як К. Алімов, Ж.-Л. Бержель, С. Васильєв, І. Венедіктова, Ж. Завальна, І. Ізарова, Л. Кадієт, Р. Ханик-Посполітак, О. Харитонова, Є. Харитонов, Н. Пархоменко, В. Шаганенко та інші. Динамічний розвиток та удосконалення моделей судового правозастосування України та Франції, аналіз їхніх спільних та відмінних рис зумовлюють інтерес до проведення такого дослідження.

Постановка завдання. Мета статті - проаналізувати моделі судоустрою та судового правозастосування України та Франції, виявити їх спільні та відмінні риси.

Результати дослідження. Модель судового правозастосування держав континентального права має авторитарний характер із вагомою активною роллю суду на всіх стадіях процесу. В процесуальному законодавстві більшості країн цієї групи віддається перевага імперативному регулюванню процесуальних відносин. Процесуальне право відповідно до специфіки судочинства є публічним [4, с. 113].

Як зазначає Н.М. Пархоменко, у практиці судів континентальної Європи поступово здобуває визнання судове право і пов'язаний з ним орієнтований на конкретні прецеденти стиль юридичного мислення. Доктрина правових джерел, яка утворилася в позитивістській теорії права, більше не відповідає сучасним методам здійснення правосуддя [5, с. 260]. Наразі модель судового правозастосування держав континентального права вирізняється тим, що розширюється практика звернення до судових прецедентів, зроблених ЄСПЛ, а також судових рішень країн континентальної Європи [5, с. 289]. Практику ЄСПЛ для більшості держав континентальної правової сім'ї слід розглядати як одне із джерел права, що спонукає до вжиття заходів по усуненню недоліків в національній правовій системі. Рішення ЄСПЛ мають прецедентне значення згідно з принципом солідарності. Правовий плюралізм судового прецеденту слід розуміти як «модель, яка містить застосовані принципи», що відображає синтез судових актів, які містять базові правові принципи чи основоположні ідеї [6].

Практика ЄСПЛ має вплив на судове правозастосування, поступово змінюючи та удосконалюючи його, розвиваючи практику національних судів 3 урахуванням загальноєвропейських принципів та стандартів. Суди не наділені правотворчими функціями, а вищі судові інстанції не формулюють в судовому рішенні нових норм права, відповідно, й не виносять рішень загальнообов'язкового характеру. У процесі розгляду справи судді тлумачать зміст норм права.

Модель судового правозастосування держав континентальної правової сім'ї безперечно має низку вищезгаданих рис, які є спільними для усіх держав. Водночас кожна держава має свою самобутню й унікальну систему судоустрою та механізм судового правозастосування. Розглянемо їх на прикладі правових систем Франції та України, які є типовими представниками континентальної правової системи.

Зокрема, в Україні діє єдина судова система, до складу якої входять Верховний Суд, вищі спеціалізовані суди (Вищий суд з питань інтелектуальної власності та Вищий антикорупційний суд), апеляційні та місцеві суди. Система судів України $є$ досить розгалуженою за будовою та обмеженою за спеціалізацією. Вітчизняні суди спеціалізуються на розгляді цивільних, кримінальних, господарських, адміністративних справ, а також справ про адміністративні правопорушення [7].

Єдиним органом конституційної юрисдикції є КСУ, основною функцією якого є забезпечення верховенства Конституції, їі охорона та захист. До основних повноважень КСУ належить: офіційне тлумачення Конституції України, вирішення питання щодо конституційності нормативно-правових актів України та інші повноваження, визначені ст. 7 Закону України «Про Конституційний Суд України» [8].

На відміну від України, судова система Франції багатоступенева. До її складу входять: Касаційний суд (очолює систему загальних судів, складається 3 шести палат та вирішує питання права, а не факту), апеляційні та спеціальні суди, які розглядають різні категорії справ (квазісудові органи). У судовій системі Франції є трибунали нижчої інстанції, в яких справи розглядаються суддею одноособово. $€$ торгові суди, палата 3 обвинувачень

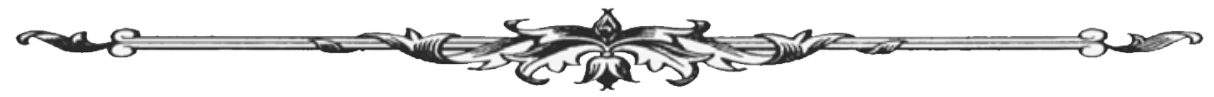


(розглядає дисциплінарні провадження щодо офіцерів судової поліції), палата жандармерії (справи неповнолітніх) тощо. Кримінальні справи розглядаються трибуналом поліції. Попереднє слідство здійснюється слідчим суддею. У Франції діють суди присяжних (суди асизів), що розглядають тяжкі кримінальні злочини. $Є$ система адміністративного правосуддя, що включає адміністративні суди, суди адміністративного оскарження та суд найвищої інстанції - Державну раду [9, с. 144]. Якщо виникає спір між юрисдикціями судових і адміністративних гілок, справу розглядає Суд юрисдикційних суперечок (Tribunal des conflits) - спеціальний суд, що складається з рівної кількості суддів Касаційного суду і державних радників. Охорону Конституції, вирішення питань стосовно конституційності законів та їх відповідності міжнародним договорам Франції забезпечує Конституційна рада [10, с. 27-28].

Таким чином, французька модель судоустрою вирізняється від української розгалуженістю та багаточисельністю судових органів, спеціалізацією та можливістю залучення до судового правозастосування непрофесійних суддів (приміром, банкірів, промисловців, представників спілок роботодавців тощо). Французька модель конституційного контролю, на відміну від української, здійснюється двома органами - Конституційною радою (вирішує питання конституційності актів парламенту) та Державною радою (вирішує питання конституційності та законності актів органів виконавчої влади).

Моделі судового правозастосування України та Франції розглянемо з урахуванням особливостей цивільного процесу.

Порядок розгляду та вирішення судом цивільних справ в Україні регулюється Конституцією України, Цивільним процесуальним кодексом України від 18.03.2004 р., Законом України «Про міжнародне приватне право» від 23.06.2005 р., а у Франції - Цивільним процесуальним кодексом Франції (Code de Procédure Civile) 2007 р., що являє собою модифікацію положень Цивільного процесуального кодексу 1975 р., без включення норм Цивільного процесуального кодексу 1806 р. (Наполеона) та Кодексу судоустрою (Code de l'organisation judiciaire) від 16.03.1978 р. Конституція Франції (1958 р.) включає Розділ VIII «Про судову владу», що складається 3 трьох статей (ст. 64-66), що проголошує принцип незмінності суддів, принцип заборони довільного позбавлення волі. Тому їі роль, як джерела цивільного процесуального права, полягає в тому, що норми Конституції Франції є фундаментом та передумовою судової реформи.

Французька модель судового правозастосування включає три стадії: порушення справи, включаючи підготовку справи до розгляду; вивчення та аналіз обставин справи (судове слідство); винесення рішення у справі. Тривалий час основу теорії французького процесуального права складало вчення про те, що процес - це справа приватна, проте наразі у французькій доктрині панує думка, що судова справа належить до сфери публічного права [11, c. 67-68].

Згідно з основами французького цивільного процесу ініціатива розгляду справи судом у більшості випадків належить сторонам. Формою звернення до суду, як і в Україні, є позов. Як зазначає Ж.-Л. Бержель, позов означає право заявника бути заслуханим по суті скарги, а для відповідача - це можливість встановити правомірність скарги. Разом з тим є справи, які розглядаються суддею за відсутності спору, приміром, про усиновлення [12, с. 531]. Відмінною рисою французької моделі судового правозастосування є можливість подання спільної заяви до суду, в якій сторони фіксують свої спірні позиції. Спільною рисою є наявність інституту посередництва. Проте, якщо у Франції модель медіації застосовується з 1996 року, то для України така модель є новою. Судове посередництво проводиться до початку розгляду справи по суті, за згодою сторін, про що видається ухвала, і, відповідно, зупиняється провадження у справі. Французька модель посередництва передбачає можливість ії застосування як до спору загалом, так і до окремої його частини, а посередником у справі може виступати фізична особа або організація. Водночас посередництво не спричиняє припинення повноважень судді в справі [13, с. 355].

Визначення форми провадження у Франції, як і в Україні, залежить від складності справи або ж часу, витраченого для іiї підготовки до розгляду. Прості справи одразу переда-

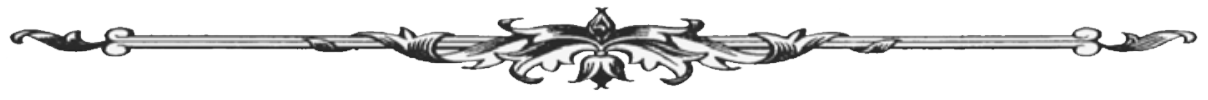


ються до суду та вирішуються за спрощеною процедурою. Складні справи, частіше комерційні, підлягають попередній підготовці [13, с. 356-357].

Судове засідання - це особлива форма проведення процесуальних дій, яка проводиться у залі судових засідань (спеціально обладнане приміщення), i лише в окремих випадках процесуальні дії можуть вчинятися за межами суду. Центральною стадією провадження у справі є розгляд справи по суті, під час якого спір розглядається на підставі зібраних у підготовчому провадженні матеріалів [14, с.109-110].

Складником французької моделі судового правозастосування, як і української, є дебати. Дебати між сторонами - це елемент доказування. Дебати відбуваються перед колегією суддів, які в подальшому обговорюють та розглядають справу. Докази подаються в усній, документальній формах або встановлюються шляхом слідчих заходів як допоміжного інструменту (у формі експертизи). Більшу цінність мають докази, подані в письмовій формі. Суд, перед яким розглядається справа, має право не брати до уваги докази, подані із запізненням. Сторона може вимагати надання конкретних доказів, не згаданих іншою стороною, якщо такі докази можуть містити елементи, які могли б мати значення для розгляду справи. Якщо запитувана сторона відмовляється подати таке прохання, сторона, що запитує, може подати офіційний запит про надання доказів, які будуть включені до справи. Якщо запитувана сторона відмовляється надати запитувані докази, запитуюча сторона може попросити суд наказати стороні, яка не виконала угоду, приступити до такого виконання, адже суд має повну свободу вирішувати питання про необхідність та корисність документа в спорі. 3 причин економії часу дебати можуть відбуватися перед одним суддею, за умови виконання двох умов: по-перше, сторони мають домовитися про це, i, по-друге, суддя, повинен підготувати звіт для інших суддів. Саме за таких умов рішення буде відповідати вимогам колективного рішення. Зазвичай на практиці важко перевірити реальність колективного обговорення. Тому, як зазначає Л. Кадіє, модель одноособових судів є доволі поширеною у Франції [13, с. 357-358].

За результатами дебатів суддя виносить рішення, яке може мати три форми: судове рішення, прийняте за участі сторін у порядку змагальної процедури (contradictoirement); судове рішення, що вважається винесеним з дотриманням змагальної процедури (réputé contradictoire); судове рішення, винесене заочно, за відсутності відповідача (par défaut). Судове рішення, що вважається результатом змагальної процедури (réputé contradictoire), описується таким чином, щоб акцентувати увагу на тому, що хоча сторона й не з'явилася до суду, це не мало ніякого процесуального значення і на рішення не вплинуло. Натомість, якщо відповідач не з'явився, рішення виноситься заочно - без його участі. Л. Кадіє класифікує судові рішення на остаточні, судові постанови по проміжним питанням та змішані (результат застосування процедури посередництва) [13, с. 359-360].

Висновки. Підсумовуючи вищевикладене, зазначимо, що спільними рисами моделей судового правозастосування цивільного процесу України та Франції є: його законодавче врегулювання цивільними процесуальними кодексами; спільність принципів цивільного судочинства (верховенства права, змагальності, публічності, пропорційності, можливості оскарження судового рішення тощо); підстава для розгляду справи судом - пред’явлення позову; проведення підготовчого засідання; моделі доказування та судових дебатів; моделі судових рішень; можливість їх оскарження; наявність інституту посередництва, але 3 властивими особливостями для кожної з держав.

Відмінності ж французької моделі судового правозастосування полягають у такому: можливість подання спільної заяви сторонами, що містить взаємні позовні вимоги, спірні питання, аргументи та докази. В Україні ж позов може бути пред’явлений спільно кількома позивачами або ж до кількох відповідачів (процесуальна співучасть) (ст. 50 Цивільного процесуального кодексу України) [15]; примирення сторін є обов'язком суду, у вітчизняному законодавстві зазначено, що суд лише сприяє примиренню сторін; сторони мають право самостійно захищати свої інтереси та вільні у виборі довіреної особи - представника, але в Україні у більшості справ, представництво в суді здійснюється винятково адвокатом. Суттєвою відмінністю французької моделі судоустрою є розгалужена система судових органів.

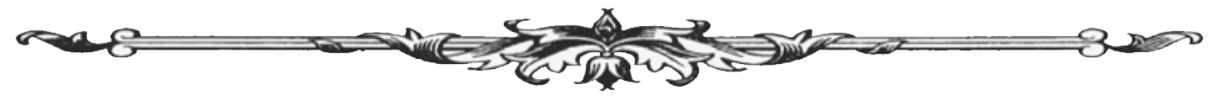




\section{Список використаних джерел:}

1. Харитонова О.І., Харитонов С.О. Порівняльне право Свропи. Основи порівняльного правознавства: Європейські традииії. Видання друге, доповнене. Харків : «Одіссей», 2006. $624 \mathrm{c}$.

2. Селіванов В.М. Право і влада суверенної України: методологічні аспекти : монографія. Київ : Вид. дім «Ін Юре», 2002.723 с.

3. Загальна теорія держави і права : підручник для студентів юридичних вищих навчальних закладів. М.В. Цвік, О.В. Петришин, Л.В. Авраменко та ін. ; За ред. д-ра юрид. наук, проф., акад. АПрН України М.В. Цвіка, д-ра юрид. наук, проф., акад. АПрН України О.В. Петришина. Харків : Право, 2009. 584 с.

4. Венедіктова І.В., Завальна Ж.В. Про можливість застосування договірного регулювання відносин щодо добровільного виконання судових рішень. Вісник Харківського національного університету імені В. Н. Каразіна. Серія «ПРАВО». 2017. Випуск 23. С. 113-116.

5. Пархоменко Н.М. Джерела права: проблеми теорії та методології: монографія. Київ : ТОВ «Видавництво „Юридична думка”», 2008. 336 с.

6. Васильев С.В. Место практики Европейского Суда по правам человека в гражданском судопроизводстве Украины. Проблемы законности. 2012. Вып. 120. URL: https://cyberleninka.ru/article/v/mesto-praktiki-evropeyskogo-suda-po-pravam-cheloveka-vgrazhdanskom-sudoproizvodstve-ukrainy-1 (дата звернення: 10.11.2019р.).

7. Про судоустрій і статус суддів: Закон України від 02.06.2016 р. № 1402-VIII.

8. Про Конституційний Суд України: Закон України від 13.07.2017 р. № 2136-VIII.

9. Соловьев А.А. Общая характеристика французской модели административной юстиции. Вестник РУДН. Серия «Юридические науки». 2013. № 3. С. 142-151.

10.Система державного управління Республіки Франція: досвід для України / авт.-уклад. Л.А. Пустовойт ; за заг. ред. Ю.В. Ковбасюка. Київ : НАДУ, 2010. 56 с.

11. Алімов К.О. Зарубіжний досвід цивільного процесу Німеччини та Франції. Юридичний науковий електронний журнал. 2017. № 6. С. 66-68.

12.Бержель Ж.Л. Общая теория права / Пер. с фр. Г.В. Чуршукова ; Под общ. ред. В. И. Даниленко. Москва : Nota Bene, 2000. 576 с.

13. Cadiet L. Introduction to French Civil Justice System and Civil Procedural Law. Ritsumeikan Law Review. 2011. № 28. P. 331-392. URL: http://www.ritsumei.ac.jp/acd/cg/law/ lex/rlr28/CADIET3.pdf (дата звернення: 10.11.2019 р.).

14.Ізарова І.О., Ханик-Посполітак Р.Ю. Цивільний процес України : навч. посіб. для студ. юрид. спец. вищих навчальних закладів. Київ : ВД «Дакор», 2018. 276 с.

15.Цивільний процесуальний кодекс України: Кодекс України; Закон від 18.03 .2004 р. № 1618-IV. URL: https://zakon.rada.gov.ua/laws/show/1618-15 (дата звернення: 14.11.2019 p.)

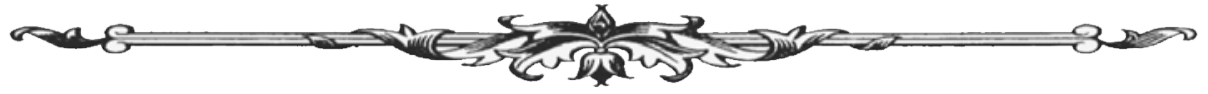

